\title{
Penanganan Permasalahan Kaum Muda dalam Budaya Populisme Masyarakat Urban
}

\author{
Linda Dwi Sholikhah, ${ }^{1}$ Saeful Hayat ${ }^{2}$ \\ 1,2Universitas Sebelas Maret, Surakarta - Indonesia
}

\begin{abstract}
Young people are those who are so easily influenced by modern and primitive trends. They are a group of people who are quickly touched by change. The development felt fast in the city. Culture of young people who follow the modern trend needs supervision and guidance so as not to fall into the negative direction or even erode the identity of the nation. In its development the people should have opportunities in social life and an active role in government. However, in its development there are several problems that arise so that proper handling of self, family and school environment, and government is needed. This is done to improve the youth activism as the next generation of nation that is expected to bring this country more prosperous and prosperous.

Kaum muda adalah mereka yang begitu mudah dipengaruhi trend modern dan primitif. Mereka adalah golongan manusia yang cepat tersentuh dengan perubahan. Perkembangan dirasa cepat didaerah kota. Budaya kaum muda yang mengikuti trend modern perlu adanya pengawasan dan bimbingan agar tidak terjerumus ke arah negatif atau bahkan mengikis jati diri bangsa. Di dalam perkembangannya rakyat seharusnya memiliki kesempatan dalam kehidupan bermasyarakat dan peran aktif dalam pemerintahan. Akan tetapi dalam perkembangannya ada beberapa permasalahan yang timbul sehingga dibutuhkan penanganan yang tepat dari diri sendiri, lingkungan keluarga dan sekolah, dan dari pemerintah. Hal tersebut dilakukan untuk meningkatkan keaktifan kaum muda sebagai generasi penerus bangsa yang diharapkan mampu membawa negara ini lebih makmur dan sejahtera.
\end{abstract}

Keywords: problems and handling; youth culture; populism of urban society

${ }^{1}$ Korespondensi: Linda Dwi Sholikhah (lindadwisholikhah@gmail.com), FKIP Universitas Sebelas Maret, Jl. Insinyur Sutami No.36 A Kentingan Surakarta 57126 - Indonesia. 


\section{Pendahuluan}

Indonesia merupakan negara berkembang yang pertumbuhan penduduknya begitu cepat. Hal tersebut mengakibatkan pertumbuhan sektor ekonomi turut berkembang cepat, khususnya di daerah perkotaan. Setelah kemerdekaan, di pusat-pusat kota mulai didirikan pabrik dan kantor-kantor pemerintahan. Dengan demikian kehidupan dikota mengalami perkembangan lebih cepat daripada didaerah pedesaan. Dengan adanya daya tarik berupa pertumbuhan ekonomi yang bagus, maka membuat masyarakat pedesaan tertarik untuk menuju ke kota.

Alasan utama urbanisasi yang dilakukan masyarakat desa menuju kota adalah pengharapan untuk dapat merubah nasib menjadi lebih baik melalui partisipasinya dalam perkembangan perekonomian. Kondisi tersebut mengakibatkan adanya populisme masyarakat urban. Populisme dalam KBBI berarti paham yang mengakui dan menjunjung tinggi hak, kearifan, dan keutamaan rakyat. Margaret Canovan (2000) mendefinisikan dan membagi populisme dalam tiga bentuk. Pertama yakni populisme wong cilik, istilah ini berorientasi kepada para rakyat kecil untuk mencapai tujuan politiknya Kedua yakni populisme otoriter yang mengharapkan lahirnya pemimpin kharismatik. Ketiga yakni populisme revolusioner yang mengemas ide-ide kolektif ketidakadilan sosial, ketimpangan sosial, kelesuan ekonomi, nasionalisme semu, dominasi elite politik, dan pemerintah otoriter.

Populisme muncul sebagai akibat dri mekanisme demokrasi yang buruk, namun tidak berarti populisme bisa menjadi solusi atas persoalan demokrasi. Tujuan kunci di balik populisme adalah bahwa rakyat harus memiliki kesempatan dan berperan aktif dalam pemerintahan. Saat ini populisme masyarakat urban sangat dirasakan melalui nasionalisme semu, yakni rasa kebangsaan yang selama ini muncul lebih banyak didominasi atas landasan konflik melalui penciptaan common enemy. Setelah kemerdekaan di kota-kota mulai dibangun sentra-sentra industri dan kantor pemerintahan. Hal ini menyebabkan banyaknya warga desa yang pindah ke kota untuk mendapatkan pekerjaan. Masyarakat urban yang dimaskud pada konteks ini mengacu pada KBBI, kata urban memiliki dua pengertian yakni sesuatu hal yang berkenaan dengan kota (bersifat kekotaan) dan orang yang berpindah dari desa ke kota. Perkembangan pertambahan penduduk di kota juga dibarengi dengan perkembangan teknologi informasi yang pesat pula. Oleh karena itu, masyarakat urban seringkali merujuk pada masyarakat yang tinggal di perkotaan dan lekat dengan karakter kekotaan yang terepresentasi melalui kepemilikan maupun ketrampilan atas teknologi informasi.

Pada kenyataannya perkembangan perekonomian dan teknologi informasi menjadi salah satu faktor yang melatarbelakangi tingginya aktivitas urbanisasi masyarakat. Menurut Tri Joko S. Haryono (1999) faktor pendorong meningkatnya urabnisasi antara lain: perbedaan pertumbuhan fasilitas dan ketidakmerataan fasilitas antara di desa dan kota, semakin membaik dan meluasnya sarana dan prasarana di kota, dan pertumbuhan industri di kota-kota besar yang banyak membuka peluang kerja. Pada umumnya faktor ekonomi yang dianggap sebagai faktor utama menjadi pendorong arus urbanisasi.

Menurut I Gede Ketut Suntajaya (2014) urbanisasi bukan hanya berkaitan dengan masalah demografi tetapi juga berkaitan dengan masalah ekonomi daerah asal ataupun daerah tujuan kaum urban. Bagi daerah tujuan, fenomena urbanisasi dapat mendorong pembangunan dalam artian kaum urban dapat berpartisipasi sebagai tenaga kerja. Akan tetapi jika urbanisasi tidak terkendali tentu juga akan mengakibatkan permasalahan ataupun berdampak negatif. Permasalahan yang timbul dari urbanisasi antara lain pemukiman kumuh, kemiskinan, tindak kejahatan dan pengangguran. 
Pemukiman kumuh merupakan suatu pemandangan yang wajar ditemukan di perkotaan besar. Banyak masyarakat yang tinggal di bantaran sungai, di pinggir jalur kereta api, di kolong jembatan dan di emperan toko. Selain itu kemiskinan di perkotaan disebabkan karena pekerjaan yang tidak sesuai dengan harapan dari kaum urban. Kondisi tersebut dilatarbelakangi oleh ketidaksesuaian bahkan minimnya ketrampilan yang dimiliki oleh kaum urban. Oleh karena itu, seringkali kaum urban pendatang bekerja 'serabutan'. Kondisi yang demikian seringkali menjadi pemicu munculnya kondisi yang merujuk pada tindak kriminal yakni ragam tindak kejahatan yang dikarenakan faktor ekonomi akibat tidak memiliki pekerjaan yang layak.

Saat ini tidak hanya berasal dari daerah akan tetapi banyak juga warga negara asing yang menetap dan membuka usaha di kota. Dengan adanya akulturasi budaya dari berbagai daerah dan berbagai negara, maka masyarakat perkotaan mengalami percampuan kebudayaan yang mempengaruhi setiap individu. Akulturasi budaya yang berlangsung kemudian akan mempengaruhi budaya yang telah terinternalisasi pada masyarakat, khususnya kaum muda. Kaum muda adalah mereka yang begitu mudah dipengaruhi trend modern, mengingat mereka adalah golongan manusia yang cepat tersentuh dengan perubahan. Batasan pemuda jika berdasarkan World Health Organization (WHO) adalah seseorang yang berusia antara 10 tahun sampai 24 tahun. Jika menurut perspektif psikologi perkembangan pemuda merupakan masa dimulai pada masa remaja yang berada pada masa peralihan dari anak-anak menuju dewasa.

Singgih D. Gunarsa (1991) mengungkapkan bahwa remaja memiliki ciri-ciri antara lain kegelisahan, pertentangan, mempunyai keinginan untuk mencoba hal-hal baru, keinginan mencoba yang diarahkan pada dirinya dan orang lain, keinginan bergaul yang lebih luas, mengkhayal, berfantasi dan senang berkelompok Kaum muda senang befantasi, memiliki keinginan untuk mencoba hal-hal baru dan keinginan untuk bergaul lebih luas. Fase perkembangan ini anak muda akan rentan dan kritis. Pada tahap ini diri remaja mulai mencari jati diri untuk menentukan masa dewasanya nanti.

Kaum muda adalah harapan bangsa sebagai penerus untuk mempertahankan kemerdekaan dan meningkatkan kehidupan bangsa ke arah yang lebih baik. Maka kaum muda diharapkan ikut berpartisipasi aktif dalam menyumbangkan ide, gagasan dan mengikuti program-program pemerintah. Pada dasarnya setiap rakyat memiliki kesempatan dalam membangun kehidupan bermasyarakat dan memupuk rasa persatuan dan kesatuan. Berdasarkan uraian fenomena yang terjadi maka tulisan ini akan membahas permasalahan terkait populisme masyarakat urban kemudian upaya untuk mengatasi permasalahan budaya kaum muda dan populisme yang terjadi. Kajian ini menggunakan metode studi literatur untuk menganalisis populisme masyarakat urban secara komprehensif.

\section{Populisme Masyarakat Urban dan Budaya Kaum Muda Urban}

Paul Taggart menganalogkan populisme seperti bunglon yang bisa berubah-ubah warna kulit menyesuaikan dengan kondisi lingkungannya (Baskara 2017; Taggart 2002, 2004).. Dalam kamus sosiologi populisme diartikan sebagai "suatu bentuk khas retorika politik yang menganggap keutamaan dan keabsahan politik terletak pada rakyat, memandang kelompok elit yang dominan korup, dan bahwa sasaransasaran politik akan dicapai paling baik melalui cara hubungan langsung antara pemerintah dan rakyat tanpa perantaraan lembaga-lembaga politik yang ada" (Abercrombie, Hill, dan Turner 2010). Populisme adalah paham yang meng- 
utamakan kepentingan rakyat dan masyarakat umum yang bersifat kolektif kolegial akan tetapi kerap dimanfaatkan kelompok kepentingan yang sedang bertarung dalam gelanggang elektoral. Tujuan kunci di balik populisme adalah bahwa rakyat banyak harus memiliki kesempatan dalam masyarakat dan peran aktif dalam pemerintahan. Semua rakyat memiliki hak dan kewajiban yang sama di mata pemerintahan.

Masyarakat menurut Soekamto (dalam Hakito dan Widyantoro 2016) adalah kesatuan hidup manusia yang berinteraksi sesuai dengan sistem adat istiadat tertentu yang bersifat berkesinambungan dan terikat oleh rasa identitas bersama. Sedangkan urban menurut KBBI yaitu orang yang berpindah dari desa ke kota. Oleh karena itu, merujuk pada Olih Solihin (2015) masyarakat urban dapat diartikan sebagai masyarakat yang pindah dari desa ke kota dan tinggal di kota yang mempunyai sifat ke kota-kotaan. Berdasarkan pengertian ahli tersebut maka dapat disimpulkan bahwa masyarakat urban yaitu masyarakat yang pindah dari desa ke kota dan tinggal di kota sehingga memiliki sifat kekota-kotaan. Selain itu masyarakat tersebut saling berinteraksi sesuai dengan adat istiadat tertentu yang terikat rasa identitas bersama. Berdasarkan beberapa pengertian tersebut maka dapat ditarik kesimpulan makna dari populisme masyarakat urban yaitu rakyat yang pindah dari desa ke kota dan bertempat tingggal di kota, saling berinteraksi sesuai dengan adat istiadat tertentu yang memiliki kesempatan dan diharapkan berperan aktif dalam pemerintahan demi memajukan bangsa.

Menurut Hamdani M. Syam (2015) budaya adalah sesuatu yang tidak terpisahkan dengan sosial. Jika membicarakan tentang sosial maka tertuju pada masyarakat dan akan berhubungan dengan budaya. Budaya didefinisikan secara harfiah sebagai peradaban, kemajuan berfikir dan akal budi, meliputi cara berfikir, berkelakuan dan cara manusia berhubungan dengan manusia lain. Sejalan dengan teori Milner dan Browitt (2002) terkait budaya yang didefinisikan sebagai satu keseluruhan sistem yang kompleks mengandung ilmu pengetahuan, kepercayaan, kesenian, kesusilaan, undang-undang, adat istiadat, serta kebiasaan yeng diperoleh manusia sebagai anggota masyarakat. Berdasarkan pendapat para ahli di atas maka dapat dimaknai bahwa budaya dapat diartikan sebagai kelakuan. Jika dihubungkan dengan kaum muda maka dapat disimpulkan akal budi dan kelakuan yang dilakukan oleh para kaum muda.

Pemuda diidentifikasikan dengan generasi muda yang merupakan generasi bangsa untuk menentukan perubahan di masa depan. Batasan dari konsep pemuda jika berdasarkan World Health Organization (WHO) yakni seseorang yang berusia antara 10 tahun sampai 24 tahun. Literatur lain menyebutkan bahwa youth atau pemuda sebagai adolescence, yaitu seseorang yang berusia 12-13 tahun hingga 21-22 tahun. Adapu la batasan pemuda dengan tingkat pendidikan yaitu mereka yang di junior high schol hingga college dan mulai bekerja (Danbury 1983, 175).

Pada dasarnya terdapat persamaan mengenai pengertian generasi muda yaitu sebagai generasi peralihan yang dalam pandangan orang tua dianggap belum dewasa, namun generasi muda merupakan generasi penerus bangsa yang harus dipersiapkan dalam mencapai cita-cita bangsa, Oleh karena itu pemuda diharapkan kritis, ikut aktif dalam menjalankan program pemerintah dan ikut berpartisipasi dalam kemajuan bangsa dan negara. Jika kaum muda pasif ataupun lebih mementingkan kepentingan maka akan hancurlah harapan bangsa ini. Dengan demikian akan menjadi lebih baik jika para pemuda diberikan pengetahuan dan kesadaran untuk aktif dalam kehidupan sehari-hari baik kepada keluarga, sekolah maupun lingkungan masyarakat. 
Dalam perkembangannya, peran generasi muda saat ini justru mulai menurun, hal ini tidak lepas dari permasalahan dan hambatan yang dihadapi oleh generasi muda, hambatanhambatan tersebut antara lain seperti kurangnya kesadaran diri kaum muda dalam mendukung proses pembangunan. Hal ini terlihat adanya korupsi dan politik kekuasaan. Selain itu sifat generasi muda yang masih mudah terpengaruh oleh hal-hal yang bersifat sepihak dan cenderung negatif. Misalnya hura-hura, nongkrong, malas belajar, hilangnya sopan santun, membentuk geng dan pergaulan bebas. Kondisi tersebut juga dapat ditinjau melalui sifat dari generasi muda yang kadang masih menggantungkan, baik kepada orang tua, pimpinan, ataupun orang lain. Misalnya saat ini kaum muda tidak mau bekerja keras akan tetapi memilih untuk meminta kepada orang tua, hilangnya rasa malu bergantung pada orang lain.

Perkembangan media dan komunikasi yang sarat atas nilai kompetisi membuat masyarakat khususnya kaum muda untuk terus melakukan improvisasi dan upgrading skill. Namun pada kenyataannya, kaum muda justru kurang siap dalam menghadapi era globalisasi dewasa ini. Hal ini ditunjukkan dengan banyaknya kasuskasus penyalahgunaan penggunaan dunia maya melalui gadget. Kurang adanya kerjasama yang saling bermanfaat demi tercapainya suatu tujuan serta pengaruh pola pemikiran liberalisme dan kapitalisme yang di dasari oleh kehidupan individualisme akan merusak semboyan hidup dalam bekerjasama dan bergotong-royong serta jiwa kekeluargaan yang menjadi ciri khas dari bangsa Indonesia. Hal ini ditunjukkan sudah mulai pudarnya rasa gotong royong dan saling membantu antar individu. Misalnya terjadi bentrok antar suku, antar agama, dan saling menjatuhkan lawan demi kepentingan politik. Pada konteks tersebut pemuda kurang perhitungan dalam mengambil tindakan, karena terpengaruh oleh egonya. Hal ini ditunjukkan dengan adanya pertikaian dan kesalahfahaman antar anggota. Misalnya kejadian polisi berkelahi dengan TNI.

Degradasi peran generasi muda juga merujuk pada akar permasalahan laten yang terjadi di Indonesia. Dimulai dari masih banyaknya perkawinan di bawah umur dan putus sekolah. Fenomena ini banyak kita temui di kota-kota besar, adapun faktor penyebabnya yaitu kurangnya rasa tanggung jawab untuk meraih masa depan, selain itu faktor hamil di usia sekolah. Hal tersebut berkaitann dengan pergaulan bebas yang membahayakan sendi-sendi moral bangsa. Saat ini marak sekali fenomena ini terjadi. Kaum muda suka nongkrong di club, bangga dengan memamerkan kemolekan tubuhnya, hamil diluar nikah, dan kumpul kebo. Dengan adanya teknologi canggih, misalnya smartphone dan internet yang disalahgunakan untuk prostitusi, membuat vidio asusila dan mengakses vidio asusila. Sejalan dengan kondisi tersebut merebaknya penggunaan NAPZA (Narkotika, Alkohol, Psikotropika, dan Zat Adiktif) di kalangan remaja juga menjadi keprihatinan belakangan ini. Kaum muda banyak diincar oleh para bandar NAPZA sebagai pengkonsumsi maupun pengedar NAPZA. Kehidupan di kota yang sulit mencari pekerjaan dapat menjerumuskan orang sebagai pedagang barang haram. Selain itu gaya hidup orang-orang kaya terpengaruh oleh lingkungan dan juga gaya 'kebarat-baratan'. Problem kehidupan sosial, misalnya mengahadapi pergeseran nilai dan terpecahnya integritas moral. Para kaum muda mulai menghilangnya rasa malu. Acuh terhadap tetangga ataupun lingkungan, individualis, mengumbar kemesraan di depan umum padahal bukan muhrim, cara berpakaian yang terbuka dan merasa bangga dengan kehidupan yang menampilkan kemewahan. Anak-anak SD yang pacaran dan menggunakan hp untuk komunikasi di jejaring sosial. 


\section{Permasalahan dan Penanganannya Budaya Kaum Muda dalam Konteks Populisme Masyarakat Urban}

Adapun permasalahan yang diungkapkan oleh Sarlito Wirawan Sarwono (1992), pada umumnya kota diasosiasikan dengan pengangguran, kemiskinan, polusi, kebisingan, ketegangan mental, kriminalitas, kenakalan remaja, seksualitas dan sebagainya. Akan tetapi tidak hanya dalam hal lingkungan fisik saja, namun kota yang tidak menyenangkan juga merujuk pada persoalan lingkungan sosialnya. Selanjutnya Bintarto (1989) mengatakan bahwa kemunduran lingkungan kota yang juga dikenal dengan istilah "Urban Environment Degradation" pada saat ini sudah meluas di berbagai kota di dunia, sedangkan di beberapa kota di Indonesia sudah nampak adanya gejala yang membahayakan. Kemunduran atau kerusakan lingkungan kota tersebut dapat dilihat dari dua aspek. Pertama yakni dari aspek fisis (environmental degradation of physical nature), yaitu gangguan yang ditimbulkan dari unsur-unsur alam, misalnya pencemaran air, udara, kurangnya lingkungan hijau, bising, pemukiman kumuh, dan kemacetan.

Kedua merujuk pada aspek sosial-masyarakat (environmental degradation of societal nature), yaitu gangguan yang ditimbulkan oleh manusianya sendiri yang menimbulkan kehidupan yang tidak tenang, tidak nyaman dan tidak tenteram antara lain: kejahatan, pengangguran, kurangnya rasa gotong royong, kurang mengenal antar tetangga, rendahnya rasa sosial, individualis, dan banyaknya mencari keuntungan diri sendiri.

Berdasar pada kondisi tersebut maka terdapat beberapa upaya untuk menangani permasalahan antara lain melalui pengembangan potensi kaum muda, memandirikan kaum muda, dan memberikan kemampuan untuk beradaptasi dan berperilaku dalam mengatasi tantangan dan kebutuhan hidup sehari-hari. Upaya penanganan permasalahan dapat dilaksanakan dalam lingkup diri sendiri, keluarga, sekolahan, dan kepemerintahan. Jika berfokus pada penanganan masalah dalam ranah pribadi maka terdapat beberapa hal yang menjadi perhatian seperti menyaring setiap budaya asing yang masuk ke Indonesia, mempromosikan budaya Indonesia ke kancah internasional untuk menumbuhkan rasa cinta budaya Indonesia, menyukai dan menggunakan produk-produk dalam negeri, hingga pada upaya mematenkan setiap budaya Indonesia serta mempublikasikannya agar tetap terjaga agar tidak luntur terbawa arus globalisasi selain itu tidak hilang karena diklaim negara lain.

Selain itu sebagai individu yang mandiri maka generasi muda dapat menguatkan keteguhan pada nilai religius, spiritualis dan memupuk rasa kebhinekaan. Sejalan dengan upaya tersebut, maka sikap empati dalam diri untuk saling membantu antar sesama juga akan terpupuk dalam setiap individu muda. Oleh karena itu, maka secara tidak langsung juga akan berpengaruh pada proses penumbuhan rasa senang dan aktif dalam mengikuti program-program pemerintah. Sehingga dapat meningkatkan tingkat partisipasi generasi muda proses pembangunan Indonesia secara keseluruhan.

Efektifitas upaya penanganan permasalahan masyarakat urban khususnya generasi remaja juga turut diimplementasikan melalui ranah keluarga dan proses pendidikan yang dilalui oleh individu tertentu. Terdapat beberapa upaya yang dapat dilakukan orang tua dalam menciptakan suasana akrab dan lebih peka terhadap anak. Hal tersebut dapat menumbuhkan kekompakan dan kebersamaan di dalam keluarga. Sejalan dengan hal tersebut, orang tua juga dapat memberikan arahan dan contoh yang baik untuk anak-anak. Beberapa upaya yang dapat diimplementasikan dirumah tersebut juga dapat diimbangi dengan bentuk penanganan di lingkungan sekolah 
dimulai dari penerapan pendidikan karakter di lingkungan sekolah. Penjabaran pendidikan karakter di sekolah dapat ditinjau melalui pembelajaran tentang pendidikan pancasila dan kewarganegaraan dan juga bela Negara. Selain itu pendidikan karakter juga dapat dilakukan melalui internalisasi sikap cinta tanah air dan menghormati jasa pahlawan dengan mengadakan upacara setiap hari senin dan upacara hari besar nasional. Upaya lanjut dalam penanganan generasi muda di sekolah dapat disempurnakan dengan pemberian konseling sebagai upaya preventif dan kuratif.

Pada konteks ini pemerintah juga memiliki andil besar dalam upaya penanganan persoalan populis masyarakat urban melalui beberapa cara, seperti pembentukan KPK sebagai lembaga pengawas berjalannya suatu program agar amanat dari pemerintah tersampaikan dan dapat terwujud sesuai dnegan tujuan. Selain itu dalam rangka membantu masyarakat pemerintah memberikan 4 program utama yaitu Indonesia pintar, Indonesia sehat, Indonesia kerja dan Indonesia sejahtera. Program-program ini mencakup pendidikan gratis, layanan dan fasilitas kesehatan gratis bagi masyarakat, membuka lapangan pekerjaan dengan memberikan bantuan bagi para petani, dan penyediaan rumah susun bersubsidi dan jaminan sosial. Bagi warga yang kurang mampu pemerintah secara khusus menyelenggarakan program untuk masyarakat kurang mampu melalui pemberdayaan sosial, penanggulangan kemiskinan serta Program Perlindungan dan Jaminan Sosial. Program-program tersebut mencakup antara lain Program Simpanan Keluarga Sejahtera, Kelompok Usaha Bersama, Program Keluarga Harapan dan Program Raskin.

Asas adil dan merata mendasari setiap program yang dicanangkan oleh pemerintah, mengingat pemerintah telah meratakan pembangunan hingga ke desa-desa. Hal ini terlihat dengan adanya perbaikan sarana, prasarana dan fasilitas umum. Pembuatan jalan raya, perbaikan jalan, perbaikan dan penertipan terminal, stasiun, bandara, dan pasar. Pembangunan pabrik-pabrik industri di lingkungan desa khususnya pabrik garmen dan olahan makanan juga menjadi ruang alternatif dalam penanganan masalah populisme masyarakat urban. Upaya tersebut dapat dioptimalkan melalui pola pemberdayaan kerja sama antar kementerian atau satu kementerian yang melibatkan unsur non pemerintah. Misalnya program penyuluhan bahaya penyalahgunaan Narkoba di mana pihak terkait, baik Kemenegpora, Kemendikbud, Polri, BNN mengajak unsur non pemerintah melakukan kampanye terkait dengan hal tersebut.

\section{Simpulan}

Populisme memiliki tujuan kunci yaitu rakyat banyak harus memiliki kesempatan dalam masyarakat dan peran aktif dalam pemerintahan. Populisme masyarakat urban mengacu pada masyarakat yang bertempat tinggal di kota ataupun masayarakat dari desa yang berpindah dan menetap ke kota. Populisme masyarakat urban yaitu rakyat yang pindah dari desa ke kota dan bertempat tingggal di kota, saling berinteraksi sesuai dengan adat istiadat tertentu yang memiliki kesempatan dan diharapkan berperan aktif dalam pemerintahan demi memajukan bangsa. Hal tersebut tentu tak terlepas dari budaya kaum muda yang ada di dalam kehidupan masyarakat. Adanya kaum muda maka memiliki budaya sebagai kelakuan. Jika dihubungkan dengan kaum muda maka dapat disimpulkan akal budi dan kelakuan yang dilakukan oleh para kaum muda. Kaum muda adalah generasi muda yang merupakan generasi bangsa yang akan menentukan perubahan di masa depan. Setiap masayarakat memiliki kewajiban dalam membangun dan berpartisipasi aktif di dalam menyukseskan program-program pemerintah. Kaum muda adalah harapan bangsa ini.] 


\section{Daftar Pustaka}

Abercrombie, Nicholas, Stephen Hill, dan Bryan S. Turner. 2010. Kamus Sosiologi. ed. Desi Noviyani. Yogyakarta: Pustaka Pelajar.

Baskara, Restu. 2017. "Populisme Otoritarian Rezim Jokowi-JK." LPM Rhetor - UIN Sunan Kalijaga. https://lpmrhetor.com/populisme-otoritarian-rezim-jokowi-jk/.

Bintarto. 1989. Interaksi Desa-Kota dan Permasalahannya. Jakarta: Ghalia Indonesia.

Canovan, Margaret. 2000. "Populisme." In The Social Science Encyclopedia, ed. Adam Kuper dan Jessica Kuper. Jakarta: RajaGrafindo Persada.

Danbury, Conn. 1983. “Adolescence.” The Encyclopedia Americana: 175-80.

Gunarsa, Singgih D. 1991. Psikologi Praktis: Anak, Remaja dan Keluarga. Jakarta: Gunung Mulia.

Hakito, Bimo, dan Widyantoro. 2016. "Pesan Moral Ditengah Perilaku Masyarakat Urban: Analisis Semiotika Film Jakarta Maghrib Karya Salman Aristo." Jurnal Komunikasi Massa 1.

Haryono, Tri Joko S. 1999. "Dampak Urbanisasi terhadap Masyarakat di Daerah Asal." Masyarakat, Kebudayaan dan Politik 12(4): 67-78. http://journal.unair.ac.id/MKP@dampak-urbanisasiterhadap-masyarakat-di-daerah-asal-article-2564-media-15-category-8.html.

Milner, Andrew, dan Jeff Browitt. 2002. Contemporary Cultural Theory. London: Routledge.

Sarwono, Sarlito Wirawan. 1992. Psikologi Lingkungan. Jakarta: Grasindo.

Solihin, Olih. 2015. "Terpaan Iklan Mendorong Gaya Hidup Konsumtif Masyarakat Urban.” JIPSi: Jurnal Ilmu Politik dan Komunikasi 5(2): 41-50. https://ojs.unikom.ac.id/index.php/jipsi/article/ view/225.

Suntajaya, I Gede Ketut. 2014. "Faktor-faktor yang Mempengaruhi Terjadinya Urbanisasi di Provinsi Bali." Piramida 10(2): 61-70.

Syam, Hamdani M. 2015. "Globalisasi Media dan Penyerapan Budaya Asing, Analisis pada Pengaruh Budaya Populerkorea di Kalangan Remaja Kota Banda Aceh.” Avant Garde 3(1): 54-70.

Taggart, Paul. 2002. "Populism and the Pathology of Representative Politics." In Democracies and the Populist Challenge, ed. Mény. Yves dan Yves Surel. MacMillan: Palgrave, 62-80. (3): 269-88. 